УДК 330.34.1:656.2

\title{
ОСОБЛИВОСТІ ІННОВАЦІЙНОГО РОЗВИТКУ КОЛІЙНОГО ГОСПОДАРСТВА ЗАЛІЗНИЧНОГО ТРАНСПОРТУ УКРАЇНИ
}

\author{
Каличева Н.С., к.е.н., доцент, \\ Тихонравов С.М., к.т.н., доцент, \\ Біляєва Я. Б., магістр (УкрДУЗТ)
}

У статті визначено, щуо сьогодення потребуе від залізничного транспорту прискорення темпів технологічного розвитку для забезпечення гідного рівня розвитку галузі, що, в свою чергу, потребує постійного пошуку дієвих важелів для інноваційного розвитку. Доведено, що за рахунок економічних заходів, направлених на зростання ефективності функиіонування колійної інфраструктури забезпечується результативність діяльності всієї сфери. Встановлені напрями інноваційного розвитку колійного господарства, як одного із інфраструктурних складових залізничного транспорту.

Ключові слова: інфраструктура, колія, інновації, залізнична галузь, реформування, техніка, технологія

\section{ОСОБЕННОСТИ ИННОВАЦИОННОГО РАЗВИТИЯ ПУТЕВОГО ХОЗЯЙСТВА ЖЕЛЕЗНОДОРОЖНОГО ТРАНСПОРТА УКРАИНЫ}

\author{
Каличева Н.Е., к.э.н, доцент, \\ Тихонравов С.Н., к.т.н., доцент, \\ Беляева Я.Б., магистр (УкрГУЖТ)
}

В статье определено, что наше время требует от железнодорожного транспорта ускорение темпов технологического развития для обеспечения достойного уровня развития отрасли, что, в свою очередь, требует постоянного поиска действенных рычагов для инновационного развития. Доказано, что за счет экономических мер, направленных на рост эффективности функиионирования путевой инфраструктуры обеспечивается результативность деятельности всей сферы. Установлены направления инновационного развития путевого хозяйства, как одного из инфраструктурных составляюших железнодорожного транспорта.

Ключевые слова: инфраструктура, путь, инновации, жселезнодорожсная отрасль, реформирование, техника, технология

\section{FEATURES OF INNOVATIVE DEVELOPMENT OF TRACK FACILITIES OF RAILWAY TRANSPORT OF UKRAINE}

Kalicheva N.E., candidate of economic sciences, associate professor, Tikhonravov S. N., candidate of technical sciences, associate professor, Belyaeva J. B., master (USU of RT)

Railway transport is one of the components of the transport system, which plays a significant role in determining foreign economic relations of our state. Because railroads

(C) Каличева Н.С., Тихонравов С.М., Біляєва Я.Б.
Вісник економіки транспорту і промисловості № 55, 2016 68 
play an important role in ensuring the transportation process, as among the cargo and passenger traffic. And all the changes that have occurred in the field over the past time, unfortunately, has not improved its position in the market of transport services.

It should be noted that the change in the working conditions of the railway industry over the past decade has led to a new level of use of railway network and transportation process, which caused the need to improve the industry by improving the efficiency of infrastructure usage.

Under such circumstances, it is necessary to promote innovation in the infrastructure development projects of track facilities as a necessary component of effective and secure development of the entire railway sector.

Development and implementation of innovative technologies in the development of the track facilities should take into account that the operation of the railway track hosts a variety of works on current maintenance and scheduled repair - complex-Wellness, medium and major. During their execution there is a need to carry out repairs rails, ties, translated and bridge bars, to carry out a full and a single change of rails new and staropriimny, replacement of switches and transfer beams, the formulation of ways and turnouts on the gravel, fixing ties, translated and bridge bars, and the like.

It should be noted that the innovative development of the railway infrastructure is fully reflected in the effective work of railway transport and the establishment of a solid and unshakable Foundation for its further development. That, in turn, will improve transport opportunities for the industry in servicing passenger and cargo traffic, improve transit prospects of Ukraine and will contribute to the further development of domestic transport sector in accordance with international requirements.

Keywords: infrastructure, road, innovation, railway industry, reform, technique, technology

Постановка проблеми та ї зв'язки з науковими чи практичними завданнями. Стійкий розвиток територіальних комплексів та ефективність зовнішньоекономічної діяльності багато в чому залежать від стану шляхів сполучення, які 3 одного боку відображають рівень розвитку національної економіки, а з іншого - рівень економічної безпеки країни.

Ефективне функціонування сучасної та конкурентоспроможної транспортної інфраструктури відтворює ступінь економічного розвитку держави та забезпечення інноваційного розвитку всіх галузей народного господарства.

Залізничний транспорт є однією із складових транспортної інфраструктури, яка на сьогоднішній день в нашій країні перебуває у складному матеріальнотехнічному стані, покращення якого потребує значного стимулювання інноваційних процесів, що призведе до вирішення організаційних і технічних проблем транспортної галузі.

\section{Аналіз останніх досліджень $i$} публікацій та виділення невирішених частин загальної проблеми. Проблеми інновацій та інноваційного розвитку залізничної галузі зокрема та окремих іiі господарств досліджують в роботах В.Л. Диканя, О.Г. Кірдіної, І.Л. Назаренко, М. П. Сінгаєвської, П.М. Коюди [1-7] та багатьох інших. Втім постійне вдосконалення та оновлення технікотехнологічної бази залізничного транспорту потребує більш широкого та глибокого дослідження питань впровадження нововведень в усі його господарств.

Mema. Дослідження особливостей інноваційного розвитку колійного господарства залізничного транспорту України, 3 урахуванням особливостей сьогодення та формування першочергових напрямів у його інноваційному розвитку.

Вісник економіки транспорту і промисловості № 55, 2016 
Виклад основного матеріалу дослідження. Залізничний транспорт являється однією із складових транспортної системи, яка відіграє значну роль у визначенні зовнішньоекономічних зв'язків нашої держави. Адже залізниці займають суттєве місце при забезпеченні перевізного процесу, як серед вантажних, так і - пасажирських перевезень. I всі ті зміни, які відбулися в галузі протягом останнього часу, на жаль, не сприяли покращенню iï позицій на ринку транспортних послуг.

Проведення

реформування

залізничного транспорту, яке було покликано реструктуризувати Укрзалізницю 3 метою створення конкурентного середовища на ринку послуг для залізничного транспорту, відділення залізничної інфраструктури та створення кількох конкуруючих залізничних компаній 3 вертикальноінтегрованою системою господарського управління залізничним транспортом, не сприяло ефективному та швидкому розвитку галузі.

Так, створення вертикальноінтегрованої структури управління залізничною галуззю мало б призвести до демополізації основних фондів вітчизняних залізниць за рахунок вертикальної дезінтеграції, до поліпшення інвестиційного клімату галузі, зростання фінансування, розвитку транспортної інфраструктури та покращення управління на залізничному транспорті.

Варто відзначити, що зміна умов роботи залізничної галузі за останні десятиліття призвела до нового рівня використання залізничної мережі та забезпечення перевізного процесу, що спричинило необхідність у вдосконаленні роботи галузі за рахунок покращення ефективності

інфраструктури.

За таких обставин необхідно посилювати інноваційну складову у проектах розвитку інфраструктури колійного господарства, як необхідної складової забезпечення ефективного та надійного розвитку всієї залізничної галузі.

Розроблення та запровадження інноваційних технологій у розвиток колійного господарства має враховувати, що при експлуатації залізничної колії проводяться різноманітні роботи 3 поточного утримання та планових видів ремонту - комплексно-оздоровчого, середнього i капітального. Під час їх виконання постає необхідність проводити ремонт рейок, шпал, перевідних і мостових брусів, здійснювати повне та поодиноке змінення рейок як новими, так i старопридатними, заміну стрілочних переводів і перевідних брусів, постановку колії та стрілочних переводів на щебінь, ремонт шпал, перевідних i мостових брусів, тощо.

Тому, першочерговим завданням у забезпеченні інноваційного розвитку колійного господарства виступає:

- збільшення строків міжремонтних періодів;

- зростання строків роботи елементів залізничної колії, земляного полотна та штучних споруд;

- створення таких ділянок колії, котрі на протязі тривалого часу змогли б пропускати потяги 3 великими швидкостями та із значним осьовим навантаженням;

- зниження рівня небезпечних подій на коліях;

- усунення аварійної залізничної мережі;

- зменшення рівня забруднення навколишнього середовища.

Завдяки інноваційним впровадження відбувається поступове покращення функціонального стану залізничної колії. Зокрема, приблизно шістдесят років тому залізниці України почали експлуатувати безстикову колію, тобто колію, на якій немає стиків між рейками. Сучасні прогресивні технології дають можливість створювати безстикову колію довжиною до блок-ділянки і навіть до перегону. Зварювання довгих рейкових

Вісник економіки транспорту і промисловості № 55, 2016 
плітей в одну виконується з виготовленням високоміцних ізолюючих стиків безпосередньо в колії із використанням спеціальних ізоляційних матеріалів, клейових сумішей та технологічної оснастки, також застосовується вварювання рейок 3 клеєболтовим ізолюючим високоміцним стиком промислового виконання у пліті та в зрівнювальні прольоти безстикової колії. Цей метод дає змогу зменшити експлуатаційні витрати на поточне утримання колії та поліпшити екологічні умови під час проходження рухомого складу за рахунок зменшення шуму.

Продовжується впровадження на магістралях нероздільного пружного скріплення типу КПП-5. При цьому відпадає необхідність двічі на рік виконувати роботи по докручуванню та змащенню болтів клемно-болтового скріплення, яких на 1 км колії припадає від 14 до 16 тис. грн, що також призводить до зниження витрат на поточне утримання колії.

Роботи 3 проектування плану та профілю колії проводиться в теперішніх умовах 3 мінімізацією розмірів супровідних робіт по винесенню і захисту підземних комунікацій, перевлаштуванню контактної мережі, штучних споруд, земляного полотна, укладенню швидкісних стрілочних переводів на станціях, тощо.

Запровадження ресурсозберігаючих технологій при виконанні ремонтних робіт пов'язане 3 вдосконаленням технології ведення ремонтних робіт в колійному господарстві.

Перехід від системи плановозапобіжних ремонтів до системи ремонтів 3 огляду на технічний стан основних фондів інфраструктури колійного господарства призведе до зменшення ремонтних (планових поточних i непланових) i експлуатаційних витрат та до збільшення ефекту, який може бути отриманий від «неомертвляння» вкладень, адже при використанні системи ремонту $з$ огляду на технічний стан капітальний ремонт може бути проведений пізніше ніж при системі планово-запобіжних ремонтів.

Розроблення доцільних сфер застосовування сучасної ремонтної техніки при виконанні колійних робіт дасть можливість зменшити розміри парку даних машин та знизити обсяги їх ремонту. Другий напрямок, який сприяє збільшенню економічного ефекту від використання нової високопродуктивної колійної техніки, зводиться до в того, щоб ця техніка працювала на самих вантажонапружених ділянках мережі. Це призведе до покращення стану колії на завантажених ділянках та зниження витрат на паливо i електроенергію для тяги потягів.

Але в сучасних умовах $\mathrm{i}$ за наявності значної кількості проблем в колійному комплексі, потрібно виділити першочергові інноваційні завдання для розвитку сфери, серед яких основними є:

- комплексна діагностика стану колії, особливо на найбільш вантажонапружених ділянка;

- збільшення міжремонтних термінів роботи елементів колійної інфраструктури;

- застосування інформаційних технологій для діагностики стану колії;

- розроблення та впровадження графіка ремонту залізничної колії, 3 урахуванням функціональних особливостей кожної ділянки мережі тощо.

Висновки. Тож, для підняття ефективності функціонування i конкурентоспроможності галузі в сучасних економічних умовах, необхідне значне оновлення ії матеріально - технічної бази на сучасному рівні. Адже наявність нової технологічної бази, яка б відповідала сучасним вимогам, сприятиме високій ефективності забезпечення перевізного процесу за новими технологічними схемами.

Варто відзначити, що інноваційний розвиток залізничної інфраструктури повністю відбивається на ефективній роботі залізничного транспорту та на

Вісник економіки транспорту і промисловості № 55, 2016 
формуванні надійних і непохитних основ для його подальшого розвитку. Що, в свою чергу, призведе до поліпшення перевізних можливостей галузі при обслуговуванні пасажиро- i вантажопотоків, покращить транзитні перспективи України та сприятиме подальшому розвитку вітчизняної транспортної сфери відповідно до світових вимог.

\section{СПИСОК ЛІТЕРАТУРИ}

1 Дикань В.Л. Забезпечення ефективності інноваційної діяльності підприємств залізничного транспорту: монографія / В.Л. Дикань, В.О. Зубенко. Х. : УкрДАЗТ, 2008. - 194 с.

2 Кірдіна О. Г. Інновації на залізничному транспорті та рівні їх корисності / О.Г. Кірдіна // Економіка транспортного комплексу. - 2010. - Вип. 15. - C. 124-130.

3 Дикань В.Л. Інноваційні тенденції розвитку бізнес-процесів приміських пасажирських перевезень/ В.Л. Дикань, Ю.В. Єлагін// Вісник економіки транспорту і промисловості: збірник наукових праць. Харків, УкрДАЗТ. - 2016. - Вип. 53.- С. 914.

4 Назаренко І.Л. Удосконалення методики оцінки інноваційного потенціалу локомотивного депо/ І.Л. Назаренко, В.О. Маслова, Я.О. Івануна// Вісник економіки транспорту і промисловості: збірник наукових праць. - Харків, УкрДАЗТ. 2016. - Вип. 54.- С. 330- 337.

5 Сінгаєвська М. П. Економікоінноваційна ефективність розподілу інвестиційних ресурсів на відтворення технічних засобів колійного господарства / М.П. Сінгеєвська// Збірник наукових праць Дніпропетровського національного університету залізничного транспорту імені академіка В. Лазаряна «Проблеми економіки транспорту».- Д.: ДНУЗТ. 2015. - Вип. 9. - С. 45- 49.
6 Коюда П. М. Інноваційний потенціал залізничного транспорту: сутність, структура та фактори впливу/ П.М. Коюда, Г.В. Озерська// Вісник економіки транспорту i промисловості: збірник наукових праць. - Харків, УкрДАЗТ. - 2013. - Вип. 43.- С. 41- 45.

7 Каличева Н.С. Напрями інноваційного розвитку пасажирських перевезень на залізничному транспорті/ H.Є. Каличева// Вісник економіки транспорту i промисловості: збірник наукових праць. - Харків, УкрДАЗТ. 2016. - Вип. 53.- С. 93- 96.

8 Садловська І. П. Формування інвестиційно-інноваційної концепції вдосконалення прогнозування й планування розвитку транспортної інфраструктури /I. П. Садловська //Збірник наукових праць Державного економікотехнологічного університету транспорту: Серія «Економіка і управління». - ДЕТУТ, 2012.- Вип. 20. - С. 34 - 46.

9 Каличева Н.С. Забезпечення ефективного розвитку залізничного транспорту через оновлення основних фондів колійного господарства/ Н.Є. Каличева// Вісник економіки транспорту і промисловості: збірник наукових праць. Харків, УкрДАЗТ.- 2011. - Вип. 33 - С. 45 49.

10 Сич Є.М. Інноваційноінвестиційні системи як основа розвитку матеріально-технічної бази виробництва [Електронний ресурс] / Є.М. Сич, В.П. Ільчук. - Режим доступу: http://dspace.uabs.edu.ua/bitstream/.pdf.

11 Каличева Н.С. Організація управління на підприємствах залізничного транспорту в сучасних умовах/ H.Є. Каличева// Вісник економіки транспорту i промисловості: збірник наукових праць. Харків, УкрДАЗТ. - 2014. - Вип. 45. - С. 167- 170 .

Стаття надійшла: 8.09.16p. 